保健物理, 20, 407 415（1985)

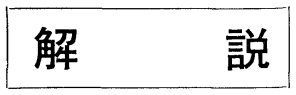

\title{
Passive 型ラドン濃度測定器について
}

飯 田孝 夫*1

（1985 年 11 月 2 日受理）

Passive Integrating Radon Monitor

Takao IIDA*1

KEY WORDS : passive, integrating, radon monitor, track detector, bare, cup, electrostatic collection, TLD, activated carbon, photographic film, electret, calibration factor, detection limit

\section{1. はじめに}

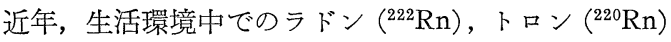
とその娘核種の吸入による肺の内部被曝線量は, 自然の 放射性核種等から受ける全被曝の大きな割合を占めると

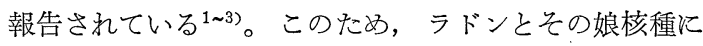
よるヒトの各集団の被曝線量を早急に求めることが世界 的治く求められている。

ラドンととの娘核種の吸入による肺の内部被曝線量を 推定するには, 生活環境中の平均的なラドン濃度レベル を測定する必要がある。この種の測定には，長期間の積 分測定が可能で, 小型, 安価, 取り扱いが容易な Passive 型ラドン濃度測定器が適している。Passive 型ラドン測 定器は種々のタイプが考案されている。検出器で大別す ると, （i 固体飛跡検出器, (ii) TLD, (iii) 活性炭, (iv) 写真用フィルム等である。

欧米では, これらの Passive 型ラドン濃度測定器が家 屋内のラドン濃度の測定に使用されている ${ }^{416)}$ 。日本で も生活環境中での日本人のラドンとその娘核種による被 曝を求める目的で, 放射線医学総合研究所や放射線影響 研究所を中心に, 全国の家屋内外のラドン濃度レベルの サーベイが進められている。種々のタイプの Passive 型 ラドン測定器がラドン濃度のサーベイに使用されている

*1 名古屋大学工学部原子核工学教室; 名古屋市千種区不老町 (

Department of Nuclear Engineering, Faculty of Engineering, Nagoya University; Furo-cho, Chikusa-ku, Nagoya 464.
ので, OECD-NEA が中心になって, Passive 型ラドン 測定器の国際的な相互比較がヨーロッパ, 北米, 太平洋 地区で実施された ${ }^{17) 。}$

著者らは, 数年来, 固体飛跡検出器の一種である硝酸 セルロースフィルムを用いた高感度の積分型ラドンモニ ターの開発研究を行ってきた ${ }^{18 \sim 20) 。 こ こ て ゙ は, ~ こ れ ら の ~}$ 経験も含めて, 種々の Passive 型ラドン濃度測定器の概 要を紹介する。

\section{2. 固体飛跡検出器を用いたラドン濃度測定法}

ラドン濃度測定には, ポリカーボネイト (Polycarbonate, 略してPC), 硝酸セルロース (Cellulose Nitrate, 略して CN), CR-39 (Allyl Diglycol Carbonate) の 3 種類の固体飛跡検出器が使用されている。これらの固体 飛跡検出器を用いたラドン測定法には，（i）Bare 法,

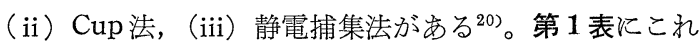
まで報告されている各方法の特性を示す。

固体飛跡検出器上に得られるトラック密度と積分ラド ン濃度の関係は次式で与えられる。

$$
X_{\mathrm{Rn}}=\frac{1}{E}\left(\frac{N}{A}-\frac{N_{\mathrm{b}}}{A_{\mathrm{b}}}\right)
$$

ここで, $X_{\mathrm{Rn}}$ は積分ラドン濃度 $\left(\mathrm{Bq} \cdot \mathrm{m}^{-3} \cdot \mathrm{hr}\right), E$ は較 正定数 (tracks $\cdot \mathrm{cm}^{-2} / \mathrm{Bq} \cdot \mathrm{m}^{-3} \cdot \mathrm{hr}$ ), $A$ は計数面積 $\left(\mathrm{cm}^{2}\right)$, $N$ は $A$ 内のトラック数, $A_{\mathrm{b}}$ はバックグラウンドの計 数面積 $\left(\mathrm{cm}^{2}\right), N_{\mathrm{b}}$ は $A_{\mathrm{b}}$ 内のバックグラウンド・トラ ック数である。式(2.1)からわかるように，第 1 表の較 正定数が大きいことは装置の検出感度が高いことに対応 
第 1 表 固体飛跡検出器を用いた Passive ラドン濃度測定法

\begin{tabular}{|c|c|c|c|c|c|}
\hline 測 定 法 & 検 出 器 & $\begin{array}{c}\text { 較正定数 } \\
\left(\frac{\mathrm{tracks} \cdot \mathrm{cm}^{-2}}{\mathrm{~Bq} \cdot \mathrm{m}^{-3} \cdot \mathrm{hr}}\right)\end{array}$ & 積算時間 & $\begin{array}{l}\text { 検出下限 } \\
\left(\mathrm{Bq} \cdot \mathrm{m}^{-3}\right)\end{array}$ & 参考文献 \\
\hline \multirow{6}{*}{ Bare 法 } & $\mathrm{CN}$ & $6.8 \times 10^{-3}$ & & & 21) \\
\hline & CR-39 & 10.0 & 1 カ月 & 7.4 & 22) \\
\hline & $\mathrm{CN}$ & 1.58 & & & 5) \\
\hline & CR-39 & 8.2 & & & 23) \\
\hline & $\mathrm{CN}$ & 2.1 & & & 24) \\
\hline & CR-39 & 4.2 & & & 25) \\
\hline \multirow{11}{*}{ Cup 法 } & $\mathrm{CN}$ & 1.16 & & & 26) \\
\hline & CR-39 & 3.4 & 1 力月 & 12.3 & 27) \\
\hline & CR-39*1 & 2.5 & 1 力月 & 29.6 & 22) \\
\hline & $\mathrm{CR}-39 * 2$ & 4.2 & 1 力月 & 14.8 & 22) \\
\hline & $\mathrm{PC}$ & 0.68 & 3 力月 & 3.7 & 28) \\
\hline & $\mathrm{CN}, \mathrm{CR}-39$ & 15.0 & 3 力月 & 3.7 & 29) \\
\hline & CR-39 & $1.9 \sim 4.3$ & & & 30) \\
\hline & CR-39 & 4.0 & & & 23) \\
\hline & $\mathrm{CN}$ & 3.2 & & & 31) \\
\hline & CR-39 & 7.0 & 3 力月 & 2.6 & 32) \\
\hline & $\mathrm{CN}$ & 3.1 & 2 カ月 & 4.9 & 33) \\
\hline \multirow{3}{*}{ 静電捕集法 } & $\mathrm{CR}-39 * 3$ & 2500 & 1 日 & 8.5 & 34) \\
\hline & $\mathrm{CN}$ & 87 & 1 カ月 & 0.4 & 35) \\
\hline & $\mathrm{CN}$ & 52 & 2 力月 & 0.7 & $18,19)$ \\
\hline
\end{tabular}

てている。

積算時間 $T(\mathrm{hr})$ 内の平均ラドン濃度 $\bar{C}\left(\mathrm{~Bq} \cdot \mathrm{m}^{-3}\right)$ は

$$
\bar{C}=\frac{X_{\mathrm{Rn}}}{T}=\frac{1}{T} \int_{0}^{T} C(t) d t
$$

と表せる。ここで， $C(t)$ は時刻 $t$ のラドン濃度 $(\mathrm{Bq} \cdot$ $\left.\mathrm{m}^{-3}\right)$ である。第 1 表の検出下限は $50 \%$ の標準偏差で求 められる平均ラドン濃度を示している。式(2.1)と (2.2) から, 平均ラドン濃度の検出下限は較正定数だけでな く, 積算時間, 計数面積, バックグラウンド等にも依存 していることがわかる。

トラック密度の計数法としては, 光学顕微鏡 (400 倍 程度）で観察し, 写真撮影した後計測するか, 画像解析 装置が用いられる。または, 大面積を計測するためマイ クロフィッシュ・リーダーが用いられる ${ }^{19,24,28)}$ 。この他 飞, トラックを自動的に計測する方法として, 固体飛跡 検出器に $\mathrm{ZnS}(\mathrm{Ag})$ 粉末を塗布し，トラックに詰まった
シンチレーター量を $\alpha$ 線源を用いて計数するシンチレー ション法年や や $\mathrm{CN}$ フィルムにアルミニウム蒸着マイラ 一膜を重ね，高電压を印加したときに生ずるスパークを 計数するスパーク・カウント法がある。

以下, 固体飛跡検出器を用いた Bare 法, Cup 法, 静電捕集法について詳しく述べる。

\subsection{Bare 法}

この方法は適当な大きさの固体飛跡検出器を壁などに 掛け，直接空気に曝すだけである。固体飛跡検出器上に は近傍空気中のラドン物よびその娘核種からの $\alpha$ 線によ ってトラックが形成される。 SAMUELSSON $5^{5)}$ やABUJARAD $5^{37)}$ や米原 ${ }^{25)}$ は実際にこの方法で家屋内のラ ドン濃度の調査を行っている。

Bare 法の原理は簡単であるが，検出器として CR-39 を用いる場合には問題がある。CR-39 は感度がよく，自 然に存在する核種からの $\alpha$ 線はすべて検出できる ${ }^{38)}$ 。こ 
のため，CR-39 表面に沈着するラドン娘核種からの $\alpha$ 線 によってもトラックができる。通常の環境条件下では， CR-39 上にできるトラックの大部分が空気中に存在する ラドンやその娘核種からの $\alpha$ 線によるよりは，表面に沈 着したラドン娘核種からの $\alpha$ 線によるものである ${ }^{37,39) 。 ~}$ ラドン娘核種が CR-39 の表面に沈着する割合は，室内 のラドン濃度よりも, フィルムの帯電状態, 空気中のエ アロゾル濃度，換気速度等に大きく依存する。このた め，CR-39 を用いた Bare 法で得られた結果の信頼度は 低い。実際, 国際相互比較でも Bare 法の結果はばらつ きの幅が大きい。

$\mathrm{CN}$ フィルムは約 $4 \mathrm{MeV}$ 以下の $\alpha$ 線が入射したとき のみエッチピットのできるトラックを形成する ${ }^{40)} \mathrm{CN}$ フィルムを Bare 法に使用すれば，表面に沈着したラド ン娘核種からの $\alpha$ 線に不感のため CR-39 より有利であ る。しかし，第 1 表からわかるように， CN の較正定数 は CR-39 に比べて約 1/5 と減少し, Bare 法は Cup 法

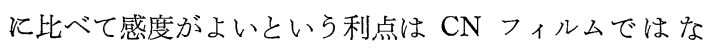
い。CN フィルム上のトラック密度からラドン濃度に変 換するとき，Bare 法ではさらに不確定な要素が入る。 すなわち，CN フィルム上のトラックはラドンだけでな くその娘核種の $\alpha$ 線によってもでさるので, トラック密 度は平均的な平衡ファクターに依存してしまう。

上述以外に Bare 法は, 空気に固体飛跡検出器を長期 間直接曝すので紫外線等により検出器自身の材質が変質 しやすいことと，トロンとその娘核種からの $\alpha$ 線によっ てもトラックが生じてしまら欠点がある。

\subsection{Cup 法}

この方法は内容積が $100 \sim 200 \mathrm{~cm}^{3}$ 程度の Cup の形状 をした容器を用いる。固体飛跡検出器は Cup の底面に 付け，Cup のロにはフィルターを取り付ける。このた め,フィルターでラドン娘核種は除去され, Cup内には ラドンだけが入る。Cup 内に短寿命のトロン（55 秒） が流入するのを防ぐため，フィルターの代りに特殊な膜 を用いたり ${ }^{14,22)}$ ，フィルターの開口面積を減らす15,32,33) 等の工夫で, 換気率を小さくしている装置も報告されて いる。

Cup内部で，ラドンが崩壞して生成されるラドン娘核 種は free 状態（エアロゾルに付着していない状態）に あるので, 短時間で Cup 内面に沈着する。Cup 底面の 固体飛跡検出器はラドンからの $\alpha$ 線以外飞, Cup 内面に 沈着しているラドン娘核種からの $\alpha$ 線によってもトラッ クを形成する。この Cup 法は Bare 法のような不確定 な要素が入りにくいので, 積分ラドン濃度とトラック密 度の間の関係は比較的よい。
現在，この Cup 法が屋内ラドン濃度測定の主流にな っている。とくに, Terradex 社の Type $F^{22)}$ と URBAN らが開発した装置 ${ }^{28)}$ が欧米では家屋内の高レベルラドン 濃度調查に使用されている6 8,11,16)。しかし, 両タイプ とも，トロンの影響の除去は不十分である。

第 1 表に揭げたCup 法は較正定数が記述されている 論文だけを発表年順に選んでいる。これら以外にも，ラ ドン濃度調査に利用されている Cup 法は多く存在して いる ${ }^{10,13,15)}$ 。第 $\mathbf{1}$ 表の較正定数は研究者によって差があ る。この違いは用いられている固体飛跡検出器の違いと Cup の形状の差による。しかしながら，Cup の形状は, ラドンとラドン娘核種の $\alpha$ 線の飛程を考慮して選択され ているので, 検出器が $\mathrm{CN}$ と CR-39 の場合の較正定数 は $1 \sim 4 \times 10^{-3}$ の間に大部分入っている。PFLIGERSDORFFER ら ${ }^{29)}$ は $15 \times 10^{-3}$, 黒澤ら ${ }^{32)}$ は $7 \times 10^{-3}$ と大き な較正定数を報告しているが，用いている Cup の形状 にそれほど差がないので，この理由は不明である。

Cup 法の欠点は較正定数が小さいため, 十分高い検出 感度を得られないことである。第 1 表の検出下限は50\% の標準偏差で測定できると推定されているラドン濃度で あって,この值まで測定可能であることを示す值ではな い。たと衤ば, 較正定数が $4.2 \times 10^{-3}$ の固体検出器の入 った Cupを $14.8 \mathrm{~Bq} / \mathrm{m}^{3}$ のラドン雾团気中に 2 カ月間 放置したとする。このとき, 固体飛跡検出器の 17.25 $\mathrm{mm}^{2}$ の面積中 ${ }^{22}$ に得られるエッチピットはわずか 15 tracks である。CR-39 の場合, バックグラウンドは 1 $\mathrm{cm}^{2}$ 当り数十から数百存在している ${ }^{27,32)}$ 。これらの事 実からも, 検出下限近くの実際の測定は困難であること が理解でさる。

この Cup 法のなかで, URBAN ら ${ }^{28)}$ は固体飛跡検出 器として PC を用いている。PC は化学エッチングでは $\alpha$ 線のエッチピットを得ることが困難なので, エレクト ロケミカル・エッチングを行っている。それでも PCは $\alpha$ 線に対して感度が低いので, $0.68 \times 10^{-3}$ と小さな較正 定数しか得られていない。しかし，マイクロフィッシュ ・リーダーを用いることで, 計数面積を $2 \mathrm{~cm}^{2}$ と広く取 り, 3 カ月間の平均で $3.7 \mathrm{~Bq} / \mathrm{m}^{3}$ と比較的高い検出感 度を報告している。この装置を $3.7 \mathrm{~Bq} / \mathrm{m}^{3}$ のラドン雾 囲気中に 3 カ月放置してもわずか 11 tracks である。バ ックグラウンドは約 $20 \mathrm{tracks} / \mathrm{cm}^{2}$ 存在している ${ }^{28)}$ 。 それゆ完，実際に実用に耐えうるデータのラドン濃度レ ベルは十数 $\mathrm{Bq} / \mathrm{m}^{3}$ 以上である。

\section{3 静電捕集法}

Cup 法は構造上，高い検出感度を得ることができな い。自然大気中のラドン濃度レベル（約 $4 \mathrm{~Bq} / \mathrm{m}^{3}$ ) まで 


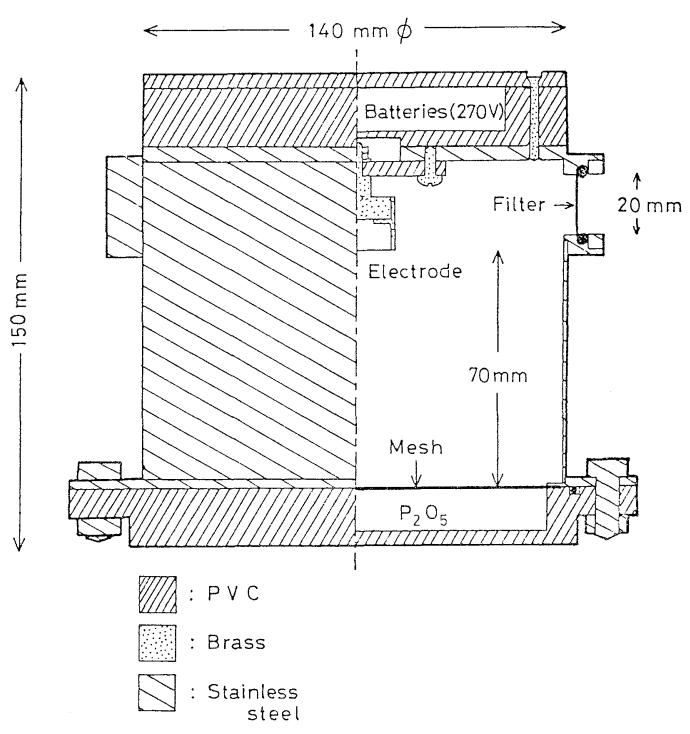

第 1 図 静電捕集積分型ラドンモニター

精度よく測定するには，何らかの方法でラドンかラドン 娘核種を濃縮捕集する必要がある。

第 1 図に著者らが開発し, 実際に生活環境中でのラド ン濃度測定に利用している積分型ラドンモニターを示 す19)。この装置は次の原理でラドンを測定している。容 器内へはフィルターを通してラドンだけが流入する。装 置の換気率は $0.75 \mathrm{hr}^{-1}$ であるので, 容器内部のトロン 濃度は外部の $1 \%$ 以下である。ラドンは $\alpha$ 崩溒して $\operatorname{RaA}\left({ }^{218} \mathrm{Po}\right)$ を生成する。 $\mathrm{RaA}$ は崩壊直後大部分正に带 電しているので, 静電場によって負の電極に 捕 集され る。電極上で崩壊した $\operatorname{RaA}$ からの $\alpha$ 線は固体飛跡検出 器に入射してトラックを作る。固体飛跡検出器を捕集電 極面から $1 \mathrm{~cm}$ 離しているので, 固体飛跡検出器上には 一椂に分布した, 径の比較的揃ったエッチピットが得ら れる。

静電捕集法では RaA を電極上に捕集するので, 第 1 表に示すように, 較正定数は Cup 法に比べて 1 桁以上 大きい。第 1 図の装置を自然大気レベルの $4 \mathrm{~Bq} / \mathrm{m}^{3}$ の ラドン雾囲気中に 2 力月間放置すると, $0.5 \mathrm{~cm}^{2}$ の計数 面積中に 150 tracks を得る。このときの CN フィルム のバックグラウンドは 10〜30 tracks であるので, 十分 精度よくラドン濃度を測定できる。

この方法の欠点は静電捕集用の電池が必要となり, Cup法に比べて構造も複雑で, 大型の装置になってしま らことである。このため, Passive 測定法の安価で取扱 いが容易といら特徵は減じられる。もう一つの問題点 は, 静電場による $\mathrm{RaA}$ の捕集効率が空気中の湿度に依
存することである ${ }^{41,42) 。 K O T R A P P A ~ ら ~}{ }^{34)}$ はこの問題に 十分な解答を与えていない。著者らは, ラドンを吸着し なくて, 除湿能力の大きい五酸化リン $\left(\mathrm{P}_{2} \mathrm{O}_{5}\right)$ で容器内 の湿度を取り除いている18,19)。

\section{TLD を用いたラドン濃度測定法}

TLD 素子を最初に Passive ラドン濃度測定に利用し たのは GEORGE ${ }^{43)}$ である。COWPER ら ${ }^{45)}$ は装置を大型 化し，検出下限を下げている。KOTRAPPA ら ${ }^{34)}$ は捕集 電極にエレクトレットを利用した装置を開発している。 これらの測定装置は屋内のラドン濃度レベルを 1 週間程 度の積算時間で十分測定可能である。GEORGE らの開発 した装置は, 実際に NYBERG $ら^{8)}$ やSWEDJEMARK ら ${ }^{12)}$ によって, 家屋内のラドン濃度測定に利用されている。 第 2 表に，いままでに報告されている TLD を用いたラ ドン測定法の特性をまとめて示す。

TLD を用いた Passive ラドン測定法はすべてが静電 捕集法を利用している。乞のため，装置の内容積は 1.5 $\sim 10 l$ と比較的大さい。容器内部の捕集電極上に TLD を取り付け，その上をアルミ蒸着マイラーで括拈ら。ラ ドンの崩壞で生成された $\mathrm{RaA}^{+}$はアルミ蒸着マイラー面 に捕集される。TLD は捕集されたラドン娘核種からの $\alpha$ 線や $\beta \cdot \gamma$ 線に照射される。環境中の $\gamma$ 線や宇宙線に よるバックグラウンドレベルは, 容器の外側に取り付け られた同一形状の TLD で求める。TLDのラドン娘核 種による被曝量 ( $\mathrm{mR} / \mathrm{hr}$ 単位の出力) を, 較正実験で 決められた定数を用いて，ラドン濃度レベルに変換す る。

TLD 法は静電捕集を利用しているので, TLD の出力 には湿度依存性がある実。際, GEORGEら ${ }^{43,44)}$ とCOWPER $ら^{45)}$ は湿度依存を報告している。GEORGE らは除湿にシ リカゲルを用い， 1 週間ごとに交換している。他の研究 者は湿度対策を行っていない。

TLD 法は第 2 表からもわかるよらに, 固体飛跡検出 器を用いた静電捕集法より感度は悪い。しかし，固体飛 跡検出器よりも, 取扱いと読取りが簡単で, TLD は再 使用できる。TLD 法の検出下限は Cup 法と同程度かそ れよりもよく， 1 週間程度の積分測定に適している。

TLD 法の欠点は, 静電捕集法を利用しているので, 測定装置が比較的大型であることである。TLD は環境 中のバックグラウンド $\gamma$ 線や宇宙線に被曝するため, ラ ドン濃度の検出下限を大きく下げることはできない。積 算時間を長くとっても, バックグラウンドも時間ととも に増加するので，検出下限をそれほど改善できない。こ のため, 通常の測定では $1 \sim 2$ 週間の積算時間が用いら れている。 
第 2 表 TLD, 活性炭等を用いた Passive ラドン濃度測定法

\begin{tabular}{|c|c|c|c|c|}
\hline 検 出 器 & （素子） & 積算時間 & $\begin{array}{l}\text { 検出下限 } \\
\left(\mathrm{Bq} \cdot \mathrm{m}^{-3}\right)\end{array}$ & 参考文献 \\
\hline \multirow{7}{*}{ TLD } & $\mathrm{LiF}$ & 1 週間 & 3.7 & $43,44)$ \\
\hline & $\mathrm{CaF}_{2}: \mathrm{Dy}$ & 1 週間 & 1.5 & 45) \\
\hline & $\mathrm{CaF}_{2}: \mathrm{Dy}$ & 1 日 & & 34) \\
\hline & $\mathrm{LiF}$ & 1 週間 & 11.1 & 8) \\
\hline & $\mathrm{CaF}_{2}: \mathrm{Dy}$ & 1 週間 & 37 & 46) \\
\hline & $\mathrm{CaSO}_{4}: \mathrm{Dy}$ & 1 日 & 30 & 47) \\
\hline & $\mathrm{CaSO}_{4}: \mathrm{Tm}$ & 3 力月 & 3.7 & 32) \\
\hline \multirow{6}{*}{\multicolumn{2}{|c|}{ 活性崖 }} & $1-3$ 日 & 3. $7^{* 1}$ & 50) \\
\hline & & 3 日 & $20^{* 2}$ & 51) \\
\hline & & 3 日 & 7.4 & $9, \quad 52)$ \\
\hline & & 1 週間*3 & $100^{* 4}$ & 53) \\
\hline & & 1 日 & 7.4 & 54) \\
\hline & & 1 日 & & $55,56)$ \\
\hline \multicolumn{2}{|c|}{$\mathrm{ZnS}(\mathrm{Ag})+$ 写真フィルム } & 170時間 & 1,480 & 57) \\
\hline \multicolumn{5}{|c|}{$\begin{array}{ll}* 2 & \text { 活性炭中に入れた TLD }\left(\mathrm{CaF}_{2}: \mathrm{Dy}\right) \text { で測定 } \\
* 3 & \text { 活性炭中にシリカゲルを入れ除湿 } \\
* 4 & \text { 測定誤差が } 18.5 \% \text { のときの值 }\end{array}$} \\
\hline
\end{tabular}

除湿問題は, 固体飛跡検出器を用いた静電捕集法と同 じく， $\mathrm{P}_{2} \mathrm{O}_{5}$ を除湿剤に用いれば解決できる。

\section{4. 活性炭を用いたラドン濃度測定法}

活性炭を用いた Passive ラドン测定法は，恵ら ${ }^{48)}$ COUNTNESS $^{49)}$ により, 地表面からのラドン放出量の測 定に初めて利用された。GEORGE $ら^{9)}$ と岩田ら ${ }^{55)}$ は活性 炭を用いる方法で屋内のラドン濃度測定を行っている。 この方法は非常に簡単で, 活性炭 100 200 g を容器に 入れ，測定したい場所に放置するだけである。活性炭法 の検出下限, 積算時間, 活性炭の量と厚さ等の理論的検 討は COHEN ら ${ }^{50)}$ が行っている。

いままでに報告されている活性炭を用いたラドン測定 法の特性を第 2 表にまとめて示す。活性炭法は他の測定 法に比べ，検出下限はそれ医どよくない。この理由は， 測定原理上積算時間を長くとれないためである。

活性炭を用いたラドン測定法は，他のPassive 測定法 と測定原理が違っている。他の Passive 法は検出器自体 を放置するのに対して, 活性炭法は次の手順で行われ る。活性炭を入れた容器を一定期間放置後, 容器をシー ルし, 活性炭を均一に混合する。ラドンと娘核種が平衡 になる時間を待って測定をする。測定は低バックグラウ ンド内で $\mathrm{NaI}(\mathrm{Tl})$ 検出器を用いて, ${ }^{214} \mathrm{~Pb}$ の 242, 295,
$352 \mathrm{keV}$ と ${ }^{214} \mathrm{Bi}$ の $609 \mathrm{keV}$ の 線の全吸収ピークを 計数する。計数值から較正定数を用いてラドン濃度に変 換する。活性炭へのラドンの吸着量ほ水蒸気の吸着量の 増加とともに減少するので, 較正定数は活性炭の重量増 加を指標として決定されている ${ }^{52)}$ 。

活性炭法によるラドン濃度測定には多くの限界があ る。活性炭はラドンだけでなく，水蒸気も吸着する。し かも, 水蒸気の吸着により, 吸着されていたラドンが脱 着されてしまう52,55)。さらに，ラドン吸着量は温度にも 依存している ${ }^{54)}$ 。活性炭を放置している間に，一度吸着 したラドンが脱着したり，崩壞するので，活性炭法で測 定されるラドン濃度は，放置期間中の完全な積分濃度に なっていない。原理上，測定終了近くのラドン濃度に影

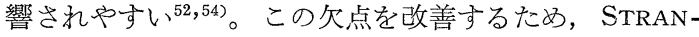
DEN ら 51) $^{2}$ TLD 素子を活性炭内に入れることで，ラ ドン積分濃度を求めようと試みている。

活性炭法の積算時間は, 水蒸気の吸着やラドンの崩壞 のため，長くとることがでさない。活性炭法の積算時間 は通常 1 〜 3 日である。GUSTAFSSON ら ${ }^{53)}$ は活性炭中 にシリカゲルを混入させることで，積算時間を 1 週間ま で延ばしている。

活性炭法には上述のような欠点はあるが，測定法が簡 
第 3 表 Passive ラドン濃度測定法の比較

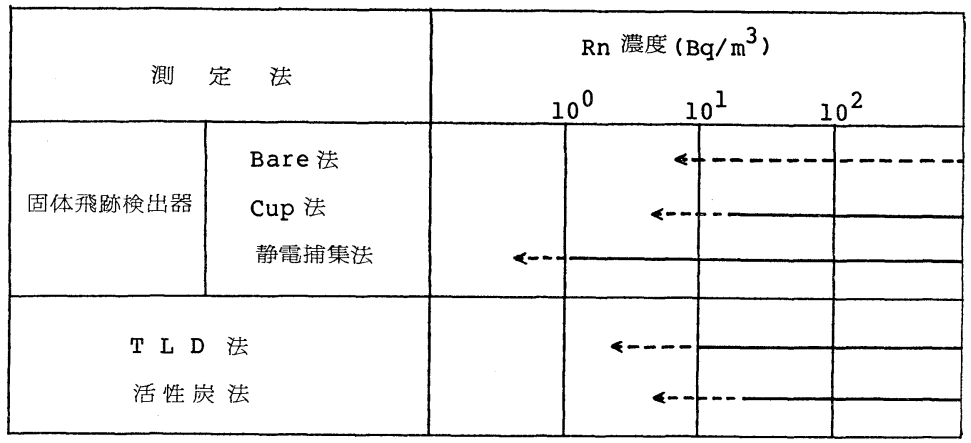

便で, 安価であり, 活性炭の再使用が可能であるので, 広範な短い積算時間の比較的高レベルのラドン測定に適 している。

\section{5. その他のラドン濃度測定法}

Passive ラドン濃度測定法には, 上述以外に, 検出器 として $\mathrm{ZnS}(\mathrm{Ag})+$ 写真フィルムを用いた静電捕集法が ある。この装置は最初の Passive 测定法で, CosTA-

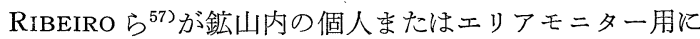
開発した。その装置の特性も第 2 表に示す。検出下限は 他の方法に比べてよくない。

ラドン濃度ではなく, 被曝評価に直接関係のあるラド ン娘核種濃度を測定する装置の開発も行われている。こ れらの装置は完全な Passive 法でなく,フィルター上に ラドン娘核種を捕集するため，吸引用の小型ポンプを使 用している。積算時間は 1 週間程度である。フィルター 上のラドン娘核種からの $\alpha$ 線の検出には，積算的な検出 器である CN フィルム ${ }^{58,59)}$, $T L D^{60 \sim 62)}$, エレクトレッ ト ${ }^{63)}$ 等が用いられている。これらの装置の大部分は鉱山 内のラドン娘核種濃度の測定を目的に開発されている。 検出下限は $5 \sim 10 \times 10^{-4} \mathrm{WL}^{* 2}$ と比較的よいので, 屋内 のラドン娘核種の測定に十分利用できる。しかし，これ らの装置はポンプを使用しているので電源を必要とし， 小型化が困難である。

ポンプを使用しない完全な Passive 法で，ラドン娘核 種の平衡ファクターを直接測定しようとする試みも最近 なされている4,31,64)。

*2 $1 \mathrm{WL}$ は, 空気 $1 l$ 当り $1.3 \times 10^{5} \mathrm{MeV}$ ポテンシャル. アルファ・エネルギー濃度である。この $1 \mathrm{WL}$ は， $3.7 \times$ $\mathrm{kBq}$ の濃度のラドンがその娘核種と放射平衡にある場合 の, その娘核種のポテンシャル・アルファ・エネルギーに 相当する。

\section{6. まとめ}

固体飛跡検出器, TLD, 活性炭, 写真フィルム等を用 いた Passive ラドン濃度測定法について述べてきた。 第 3 表に各測定法の測定可能範囲を示す。測定誤差が比 較的大きな範囲は破線で示している。

固体飛跡検出器を用いた測定法のらち，Bare 法は非 常に簡便である。しかし，検出器に CR-39 を用いる場 合, 検出器表面に沈着したラドン娘核種からの $\alpha$ 線を大 部分測っている。このため，CR-39を用いた Bare 法で 得られる結果の信頼度は低い。CN フィルムを用いた Bare 法は CR-39 のような欠点は少ないが，較正定数は 小さく感度は悪い。

Cup 法は積分ラドン濃度とトラック密度の間の関係は よい。現在，屋内ラドン濃度測定の主流になっている。 Cup 法の欠点は, 較正定数が小さいため, 十分な高い検 出感度を得られないことである。

静電捕集法は, 検出感度が高く, 自然大気中のラドン 濃度レベルまで精度よく測定でさる。しかし，電池や除 湿剤が必要となり，Cup法に比べて構造も複雑で，大型 化し，取扱いが少し面倒である。

検出器に TLD を用いる方法は静電捕集法を利用して いるので, 固体飛跡検出器を用いた静電捕集法と同じ欠 点を有している。TLD はバックグラウンド $\gamma$ 線や宇宙 線にも被曝するので，積算時間を長くして検出下限を大 きく下げることはできない。TLD 法は固体飛跡検出器 より読取りが簡単であり, 1 週間程度の積分測定に適し ている。

活性炭を用いた測定法は，検出感度はそれほどよくな いけれど，安価で測定が簡便である。活性炭の積算時間 は, 水蒸気の吸着やラドンの崩壊のため, $1 \sim 3$ 日程度 の期間しかとれない。

以上のことから，どのような環境のラドン濃度を，ぞ 
れくらいの期間間隔で, ぞれくらいの規模の測定をする かによって, 採用すべき測定法が限られてくる。密閉度 の高い家屋内や鉱山内では $40 \mathrm{~Bq} / \mathrm{m}^{3}$ 以上のラドン濃度 が期待できるので, Cup 法, TLD 法, 活性炭法で測定 可能である。乙かし, 自然大気中や換気の十分行われて いる家屋内では数 $\mathrm{Bq} / \mathrm{m}^{3}$ 程度であるので, 精度よく測 定するには, 固体飛跡検出器を用いた静電捕集法しか適 していない。

人間の生活環境中のラドン濃度は場所と季節によって 大きく違っている。それゆえ, Passive 法でラドン濃度 を測定しようとする場合, その研究目的と対象とするラ ドン濃度レベルに合った測定法を，その手法の欠点もよ く認識して，選択すべきである。

\section{参考文 献}

1) UNSCEAR; Ionizing radiation : Sources and biological effects (1982).

2) ICRP Publication 39; Principles for limiting exposure of the public to natural sources of radiation, Pergamon Press, New York (1984).

3) NCRP Report No. 78; Evaluation of occupational and environmental exposures to radon and radon daughters in the United States (1984).

4) 小林定喜; ヨーロッパに扝ける屋内ラドン濃度調 查の現況, 保健物理, 20, 198 (1985).

5) C. Samuelsson, R.B.R Persson and E. Holm; Measurement of radon and radon daughters in various Scandinavian environments, Proc. Second Special Symposium on Natural Radiation Environment, Bombay, p. 575 (1981).

6) R.L. Fleischer, A. Mogro-Campero and L.G. TURNER; Indoor radon levels in the northeastern U.S. : Effects of energy-efficiency in homes, Health Phys., 45, 407 (1983).

7) H.W. Alter and R.A. Oswald; Results of indoor radon measurements using the Track Etch (R) method, Health Phys., 45, 425 (1983).

8) P.C. NyberG and D.E. BernhardT; Measurement of time-integrated radon concentrations in residences, Health Phys., 45, 539 (1983).

9) A.C. George, M. DunCan and H. Franklin; Measurements of radon in residential building in Maryland and Pennsylvania, U.S.A., Rad. Protect. Dosimetry, 7, 291 (1984).
10) A.D. Wrixon, L. Brown, K.D. ClifF, C.M.H. Driscoll, B.M.R. GReEN and J.C.H. Miles; Indoor radiation surveys in the UK, Rad. Protect. Dosimetry, 7, 321 (1984).

11) A. WICKE; Exposure of the population to radon daughters-problems associated with the assessment of the annual dose, Rad. Protect. Dosimetry, 7, 337 (1984).

12) G.A. Swedjemark and L. MJönes; Radon and radon daughter concentrations in Swedish homes, Rad. Protect. Dosimetry, 7, 341 (1984).

13) G. Sciocchetti, F. Scacco, P.G. Baldassini, L. MONTE and R. SARAo; Indoor measurements of airborne natural radioactivity in Italy, Rad. Protect. Dosimetry, 7, 347 (1984).

14) R.L. FLEISCHER and L.G. TURNER; Indoor radon measurements in the New York capital district, Health Phys., 46, 999 (1984).

15) F. Abu-JARAd and J.H. Fremlin; Seasonal variation of radon concentration in dwellings, Health Phys., 46, 1126 (1984).

16) C.T. Hess, R L. Fleischer and L.G. TURnER; Field and laboratory tests of etched track detectors for ${ }^{222} \mathrm{Rn}$ : Summer-vs-winter variations and tightness effects in Maine houses, Health Phys., 49, 65 (1985).

17) J.C. Miles, E.J. Stares, K.D. Cliff and J. SINNAEVE; Results from an international intercomparison of techniques for measuring radon and radon decay products, Rad. Protect. Dosimetry, 7, 169 (1984).

18) Y. Ikebe, T. IIdA, M. Shimo, H. Ogawa, J. Maeda, H. Hattori, S. Minato and S. AbE; Evaluation of radon concentration and $f$-value in natural environment with $\alpha$-track detectors, Health Phys., (in printing).

19）飯田孝夫, 池辺幸正, 前田 淳, 服部隆利, 阿部 史朗；CN フィルムを用いた積分型ラドンモニタ 一, 放射線, 11, 41 (1984).

20）飯田孝夫；固体飛跡検出器を用いたラドン濃度測 定法, 放射線科学, 27, 217 (1984).

21) R.L. Rock, D.B. LovetT and S.C. Nelson; Radon-daughter exposure measurement with track etch films, Health Phys., 16, 617 (1969). 22 (H.W. Alter and R.L. Fleischer; Passive 
integrating radon monitor for environmental monitoring, Health Phys., 40, 693 (1981).

23) S.W. SkInNER and P.C. NyBERG; Method for the calculation of radon response characteristics of integrating detectors, Health Phys., 45, 544 (1983).

24) I. MÄKELÄINEN; Calibration of bare LR-115 film for radon measurements in dwellings, Rad. Protect. Dosimetry, 7, 195 (1984).

25）米原英典, 木村 博, 青山 喬, 御船政明, 阪上 正信，菅原 努; 生活環境におけるラドン平均濃 度の測定, 日本放射線影響学会講 演 要 旨集, p. 153 (1985).

26) R.L. FRANK and E.V. BEnTon; A diffusion chamber radon dosimeter for use in mine environment, Nucl. Instrum. Method, 109, 537 (1973).

27) R.L. Fleischer, W.R. Giard, A. MogroCampero, L.G. Turner, H.W. Alter and J.E. GINGRICH; Dosimetry of environmental radon: Methods and theory for low-dose, integrated measurements, Health Phys., 39, 957 (1980).

28) M. Urban and E. Piesch; Low level environmental radon dosimetry with a passive track detector device, Rad. Protect. Dosimetry, 1, 97 (1981).

29) P. Pfligersdorffer, W. Hofmann and E. POHL; Applicability of nuclear track detectors to the measurement of environmental levels of radon and decay products, Proc. 11th Int. Conf. Solid State Nuclear Track Detectors, Pergamon Press, Oxford, p.539 (1982).

30) J.C. Miles and E.J. DEW; A passive radon gas detector for use in homes, Proc. 11th Int. Conf. Solid State Nuclear Track Detectors, Pergamon Press, Oxford, p.569 (1982).

31) T. Domaísski, W. ChruŚclet.ewski and A. ZÓRAWSKI; Method of radon and decay products equilibrium factor measurement with the use of passive track detectors, Rad. Protect. Dosimetry, 8, 231 (1984).

32）黑澤龍平, 斎藤泰秀, 戸部光則, 佐藤直紀; Passive 型積算ラドン計とラドン平均濃度，日本保健 物理学会第20回研究発表会要旨集, p.73 (1985).
33）服部隆利, 飯田孝夫, 池辺幸正; $\mathrm{CN}$ フィルムを 用いた積分型ラドンモニター, 日本原子力学会秋 の分科会予稿集, p.86 (1985).

34) P. Kotrappa, S.K. Dua, N.S. Pimpale, P.C. GuPTA, K.S.V. NAmBi, A.M. Bhagwat and S.D. SomAN; Passive measurement of radon, and thoron using TLD or SSNTD on electrets, Health Phys., 43, 399 (1982).

35）黑澤龍平，山本英明; 固体飛跡検出器による環境 中のラドン濃度の測定, 第16回理工学に扣ける同 位元素研究発表会要旨集, p.110 (1979).

36) J.C.H. Miles, S.T. GAtley and K.D. ClifF; Trial of a passive radon dosimeter for miners in Wheal Jane mine, Rad. Protect. Dosimetry, 5, 95 (1983).

37) F. ABU-JARAD; Variation in long-term radon and daughters concentration with position inside a room, Rad. Protect. Dosimetry, 3, 227 (1982).

38）林 孝義; 固体飛跡検出器としての CR-39 プラ スチック，応用物理，49，705 (1980)

39）飯田孝夫，池辺幸正；トラック法による大気中ラ ドン娘核種の沈着率の測定，保 健 物 理，18，29 (1983).

40) T.M.J. KNöfel, I.A. Sachett, A. Marques, J.B. Martins and O.A.P. TAvares; Critical rate of energy loss for registration of charged particles in cellulose nitrate, Nucl. Instrum. Method, 171, 339 (1980).

41) J. Porstendörfer and T.T. Mercer; Influence of electric charge and humidity upon the diffusion coefficient of radon decay products, Health Phys., 37, 191 (1979).

42) S.K. DuA, P. Kotrappa and P.C. Gupta; Influence of relative humidity on the charged fraction of decay products of radon and thoron, Health Phys., 45, 152 (1983).

43) A.C. GEORGE; A passive environmental radon monitor, HASL 325, p. 25 (1977).

44) A.J. Breslin and A.C. George; An improved time integratin gradon monitor, Surveillance du Radon Monitoring, OECD, p. 133 (1979).

45) G. Cowper and M.R. DAvenPort; An instrument for the measurement of long-term 
average radon levels, Proc. Advances in radiation protection monitoring, Stockholm, 26-30 Iune (1978).

46) R.A. Washington and W.J. Courneya; The measurement of low concentrations radon in air, Health Phys., 45, 559 (1983).

47) T. Niewiadomski and E. RyBA; Development of TL instruments for simultaneous radon and radon daughter monitoring, Rad. Protect. Dosimetry, 6, 67 (1984).

48) K. Megumi and T. Mamuro; A method for measuring radon and thoron exhalation from the ground, J. Geophys. Res., 77, 3052 (1972).

49) R.J. Countess; ${ }^{222} \mathrm{Rn}$ flux measurement with a charcoal canister, Healih Phys., 31, 455 (1976).

50) B.L. Cohen and E.S. Cohen; Theory and practice of radon monitoring with charcoal adsorption, Health Phys., 45, 501 (1983).

51) E. Stranden, A.K. Kolstad and B. Lind; The ETB dosimeter, a passive integrating radon dosimeter combining activated charcoal and TLD, Rad. Protect. Dosimetry, 5, 241 (1983).

52) A.C. George; Passive, integrated measurement of indoor radon using activated carbon, Health Phys., 46, 867 (1984).

53) J. Gustafsson and O. Hildingson; Radon measurements in dwellings using activated charcoal, Rad. Protect. Dosimetry, 7, 203 (1984).

54) H.M. Prichard and K. MARIEN; A passive diffusion ${ }^{222} \mathrm{Rn}$ sampler based on activated carbon adsorption, Health Phys., 48,797 (1985).

55）岩田悦夫, 阪上正信; “活性炭吸着法による室内 ラドンの測定，大気中のラドン族と環境放射能” (岡部 茂編集), 日本原子力学会 (1985).
56）岩田悦夫，阪上正信；活性炭吸着法による室内ラ ドン放射能レベルの簡易測定，日本放射線影響学 会講演要旨集, p.154 (1985).

57) C. Costa-Ribeiro, J. Thomas, R.T. Drew, M.E. WRENN and M. EISENBUD; A radon detector suitable for personnel or area monitoring, Health Phys., 17, 193 (1969).

58) J.A. Auxier, K. Becker, E.M. Robinson, D.R. Johnson, R.H. BoyetT and C.H. ABner; A new radon progeny personnel dosimeter, Health Phys., 21, 126 (1971).

59) P. Duport, A.M. Chapuis and J. Pradel; Appareil individuel pour la dosimetrie des descendants du radon, Proc. Advances in radiation protection monitoring, Stockholm, 26-30 June (1978).

60) D.M. MCCuRdy, K.J. Schiagar and E.D. FLACK; Thermoluminescent dosimetry for personal monitoring of uranium mines, Health Phys., 17, 415 (1969).

61) S.F. Guggenheim, A.C. George, R.T. Graveson and A.J. BRESLIN ; A time-integrating environmental radon daughter monitor, Health Phys., 36, 452 (1979).

62) D.F. Regulla, B. Haider, J. Huber and W. JACOBI; Radon daughter monitoring with thermoluminescent detectors, Nucl. Instrum. Method, 175, 233 (1980).

63) P. Kotrappa, S.K. Dua, P.C. Gupta, N.S. Pimpale and A. H. KHAN; Measurement of potential alpha energy concentration of radon and thoron daughters using an electret dometer, Rad. Protect. Dosimetry, 5, 49 (1983).

64) R.L. FLEISCHER; Theory of passive measurement of radon daughters and working levels by the nuclear track technique, Health Phys., 47, 263 (1984). 